\title{
US effort in the development of new crops (Lesquerella, Pennycress Coriander and Cuphea)
}

Terry A. ISBELL

New Crops and Processing Research, National Center for Agricultural

Utilization Research,

Agriculture Research Service,

United States Department of Agriculture, $1815 \mathrm{~N}$.

University St. Peoria, IL 61604,

USA

<terry.isbell@ars.usda.gov>

\begin{abstract}
The US effort for the development of new crops is directed toward the advancement of crops that can be grown in rotation with traditional commodity crops, off-season production and utilization of acreage not currently under cultivation. This effort is intended to have no or minimal impact on crop rotations that are sources for food production. The high oil content and the fatty acid profiles of mustard crops make them suitable for utilization as both fuels and base stocks for functionalized industrial chemicals. Pennycress (thlaspi arvense) and lesquerella (lesquerella fendleri) are representatives of this family and have received much attention due to their potential to grow over winter in rotation with soybean production throughout the Midwest (pennycress) or as a winter annual in the desert southwest (lesquerella). Pennycress is an oilseed crop that produces $36 \%$ oil with a wide distribution of fatty acids (principal fatty acid is erucic acid 37\%) that make it suitable for production of biodiesel. The key aspect of pennycress is that its lifecycle is complete such that a full season soybean can follow its production in the same growing season. Lesquerella is an oilseed crop containing 30\% oil that is composed of $60 \%$ hydroxy fatty acids. Hydroxy fatty acids are used in a wide range of industrial and cosmetic applications. Two other New Crops currently under investigation are cuphea and coriander. Cuphea is an oilseed crop that contains $35 \%$ oil that is composed of medium chain saturated fatty acids. The current cuphea variety under investigation is high in capric fatty acid (76\%) with other cuphea species producing high levels of lauric acid. Cuphea can be grown throughout the Midwest but suffers from several agronomic traits that are currently limiting is potential adaptation. Coriander is also an oilseed crop with $25 \%$ oil where the main fatty acid is petroselinic acid (76\%). Coriander can be grown under a short season production and has potential to rotate as a second crop following winter wheat. Petroselinic acid can be ozonolytically cleaved into adipic and lauric acids both high volume industrial chemicals.
\end{abstract}

Key words: New Crops, Cuphea, Coriander, Lesquerella, Pennycress

unique chemicals not readily available and have the potential to be produced with little to no impact on food producing commodity agriculture.

Agriculture production in the US is focused on a few commodity crops, wheat cotton and the two largest crops, corn and soybean. In 2008, there was $35.2 \mathrm{M} \mathrm{Ha}$ corn in production with an average yield of $9,745 \mathrm{~kg} / \mathrm{ha}$ [1]. Soybean production in 2008 was $30.2 \mathrm{M}$ ha with an average yield of $2,722 \mathrm{~kg} / \mathrm{ha}$ [1]. Any effort in the development of a new crop must consider the consequence on the existing commodity crop that it will displace. As such, efforts from our group are directed toward crops that can grow off-season with a commodity crop or on land not currently growing a commodity crop. Secondly, the crop must produce compounds that are unique or not readily available from domestic sources. Lastly, the compounds may also serve as replacement for petroleum derived products. Utilizing these guidelines our group has been conducting research on mainly four potential crops coriander, cuphea lesquerella and pennycress. These four crops provide

\section{Coriander}

Coriander is a plant from the Umbelliferae family that is commonly grown as a condiment in food dishes as the herb cilantro. Coriander is a summer annual that has upright branching steams that produces an umbrella flora pattern and when mature the seed pod contains two seeds. The seeds have been widely harvested for their essential oil ( 1\%) linalool, 65\% of the composition of the essential oil [2-4]. Of lesser known value is the high composition of petroselinic acid contained within the seed oil. A recent survey of the chemical composition of the known coriander germplasm by Lopez et al. [5] reported that the triacylglyceride oil fraction of the seed contains (12.8-30.2\%) as shown in table 1 . The petroselinic acid content within the germplasm ranged from $57.9-74.8 \%$ relative to the other fatty acids contained within the oil with and average value of $67.9 \%$. Interestingly, some of the higher oil and petroselinic acid types also have shorter growing seasons with only 84 days from planting to harvest for the

Table 1. Variation in oil, petroselenic acid and days to harvest in coriander germplasm.

\begin{tabular}{|llll|}
\hline PI Number & Oil Content (\%) & Petroselenic (\%) & Days to Harvest \\
\hline Whole Collection & $12.8-30.2$ & $57.9-74.8$ & $64-110$ \\
& Avg. = 21.0 & Avg. $=67.9$ & Avg. $=89$ \\
Ames 26819 & 26.4 & 74.8 & 84 \\
Ames 23624 & 30.2 & 70.3 & 103 \\
\hline
\end{tabular}


highest petroselinate accession (Ames 26819). This rapid growth and maturation make coriander suitable for a double crop rotation through much of the Midwestern US where winter wheat is produced. Winter wheat is fall planted and harvested around July $4^{\text {th }}$ providing nearly 100 days of frost free days for crop development. The challenges for this type of rotation is limited mid-summer precipitation which is often very localized coupled with declining daylengths and eventually in late season when pods are maturing the potential for early season frost. In many parts of the world, coriander development has been directed toward herb or essential oil production. A fair amount of agronomic information has been published for its agriculture production and the Canadians have demonstrated annual production and developed grower guidelines including cost of production [4]. The Canadians have reported average seed yields for full season spring planted coriander between $900-1120 \mathrm{~kg} /$ ha with yields up to $2,800 \mathrm{~kg} / \mathrm{ha}$.

Production costs were reported at $\$ 403 /$ ha. We are currently evaluating several coriander accessions for mid-summer planting with intent to harvest in the fall.

Petroselenic acid, cis 6-octadecenoic acid, a unique monounsaturated fatty acid that has the potential to be converted into two useful commercial chemicals, lauric acid and adipic acid according to figure 1. Oxidative cleavage of petroselinic acid by ozone has been previously demonstrated $[6,7]$ and directly produces lauryl aldehyde and 5-oxo-pentanoic acid. Both of these compounds can be further oxidized to their corresponding fatty acids or in the case of lauryl aldehyde reduced to lauric alcohol, a major ingredient in many detergent applications. Adipic acid is a raw material for the production of nylon-6.

\section{Cuphea}

The genus cuphea represents a diverse group of species that have high oil contents containing large amounts of medium chain saturated fatty acids. Table 2 outlines a number of diverse cuphea species where individual cuphea species can produce large amounts of caprylic (8:0), capric (10:0), lauric (12:0) or myrisitc (14:0) acids. Although cuphea produces a small seed it is rich in oil with select species yielding $40 \%$ oil.

Because of its unique saturated fatty acid profile and high oil content, cuphea has attracted much interest from the detergent industry for its development as a crop. Unfortunately, cuphea suffers a number of problems that are typically associated with a new crop [8-12]. Cuphea is an indeterminate plant and begins

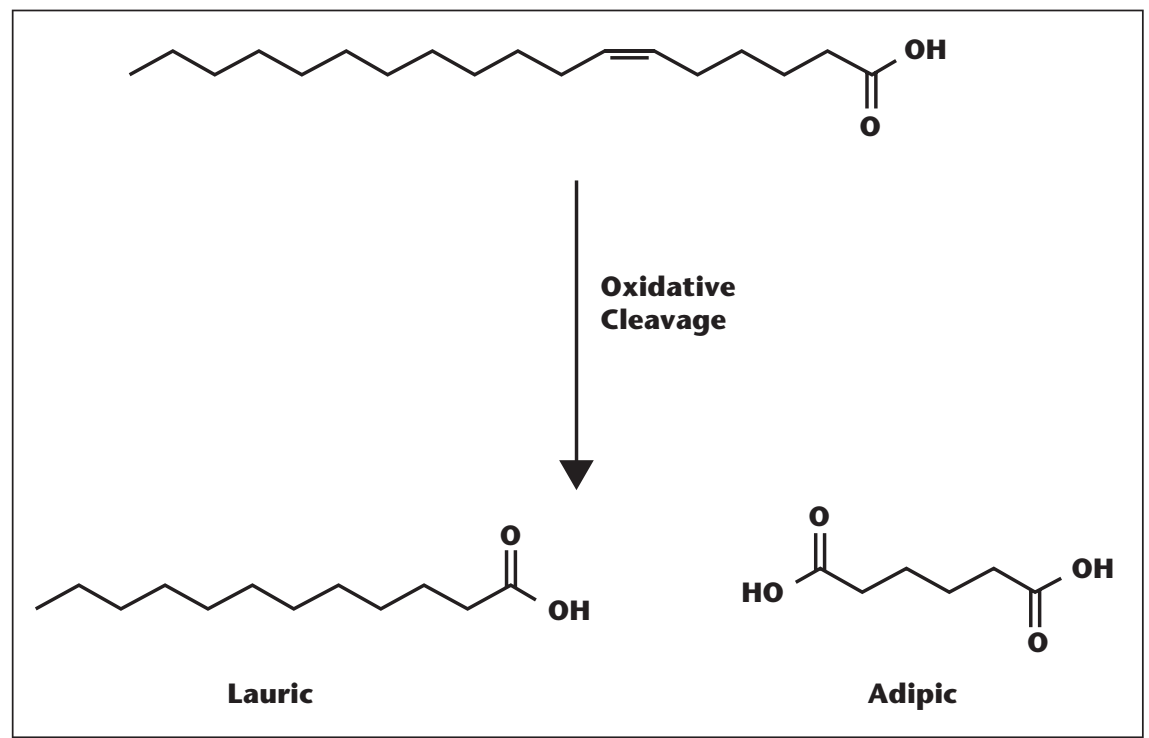

Figure 1. Oxidative cleavage of petroselenic acid as a source for detergents and monomers.

Table 2. Fatty acid profiles of various cuphea species.

\begin{tabular}{|lrrrrrrrr|}
\hline Species & $\mathbf{8 : 0}$ & $\mathbf{1 0 : 0}$ & $\mathbf{1 2 : 0}$ & $\mathbf{1 4 : 0}$ & $\mathbf{1 6 : 0}$ & $\mathbf{1 8 : 1}$ & $\mathbf{1 8 : 2}$ & 0ther \\
\hline PSR-23 & 0.8 & 74.3 & 2.9 & 4.0 & 5.3 & 0.6 & 8.0 & 3.5 \\
C. wrightii & 0.0 & 36.1 & 53.6 & 3.2 & 1.3 & 1.6 & 4.0 & 0.2 \\
C. tolucana & 0.0 & 23.1 & 65.8 & 4.2 & 1.3 & 1.0 & 3.5 & 1.1 \\
C. Viscosissima & 16.0 & 62.3 & 3.5 & 0.8 & 1.5 & 1.7 & 3.5 & 10.7 \\
C. pulcherrina & 94.4 & 3.3 & 0.0 & 0.0 & 0.6 & 0.7 & 1.0 & 0.0 \\
C. leptopoda & 0.0 & 90.9 & 2.2 & 0.4 & 1.2 & 1.5 & 2.2 & 1.6 \\
C. salvodorensis & 25.3 & 0.9 & 2.8 & 64.5 & 5.2 & 0.5 & 0.5 & 0.3 \\
Coconut & 5.1 & 4.9 & 48.3 & 21.7 & 10.6 & 2.4 & 0.0 & 7.0 \\
\hline
\end{tabular}

Table 3. Corn yields per calendar year in rotation with corn, cuphea or soybean.

\begin{tabular}{|c|c|c|c|c|c|}
\hline 2001 & & 2002 & & 2003 & \\
\hline Crop & Ibs/acre & Crop & Ibs/acre & Crop & Ibs/acre \\
\hline Soybean & & Cuphea & & Corn & 1,716 \\
\hline Soybean & & Corn & 1,371 & Soybean & \\
\hline Corn & 1,444 & Corn & 1,227 & Corn & 824 \\
\hline Cuphea & & Corn & 1,493 & Cuphea & \\
\hline Cuphea & & Cuphea & & Cuphea & \\
\hline Corn & 1,354 & Cuphea & & Corn & 1,634 \\
\hline Corn & 1,410 & Soybean & & Corn & 1,470 \\
\hline
\end{tabular}

2001 was the first year of the study.

flowering in mid-summer and continues flowering until frost kills the plant in the fall. Associated with the continuous flowering is seed shattering, where mature seed is thrown from seed pods onto the ground throughout the growing season. Because of these two undesirable traits seed yields in cuphea have remained low (220$675 \mathrm{~kg} / \mathrm{ha}$ ). A partial seed retention cross (viscosissima $\times$ lanceolata) [10] labeled PSR23 demonstrated longer seed retention characteristics but fell well short of what would be necessary to produce a commercially viable crop. The plant also suffers from a sticky coating which protects the plant from insect damage and this trait coupled with shattering and indeterminacy make harvesting cuphea by mechanical methods very challenging. Large quantities of wet green material processed through the combine results in fouling of most of the feed aspects into the combine and the deposition of a waxy material throughout all parts of the combine. Cuphea does however, provide some positive benefits to first year corn rotations where reduction in 
corn rootworm infestations were observed with a corresponding increase in seed yield [12-14]. Table 3 outlines a rotation scheme where cuphea, soybeans and corn were grown the previous year and the resulting year's corn production evaluated against damage by corn rootworm. Corn on corn rotations provided large infestations of rootworm. Soybean followed by corn provided some reduction in rootworm populations but the western corn rootworm beetle still produced damage and reduced corn yield. Minimal damage was observed when corn followed cuphea in an annual rotation which provided the highest yields of corn in this study.

Novel chemistry that has led to improved lubricants from cuphea utilizes the short chain saturated fatty acids to make highly functionalized molecules. Cuphea fatty acids when reacted with oleic acid to form estolides (figure 2) have been shown to posses superior lubricating properties than many other vegetable oils and petroleum derived products $[15,16]$. The cuphea estolides have very good cold temperature and oxidative performance yet retain the good lubricating properties that vegetable oil based materials posses (table 4). Increased branching and reduction in the degree of unsaturation within the estolide molecule provided a proportionate balance between inhibition of crystal formation and saturation.

\section{Lesquerella}

Lesquerella is a winter annual from the mustard family that is grown in the desert Southwestern region of the US. Currently field plots of lesque-

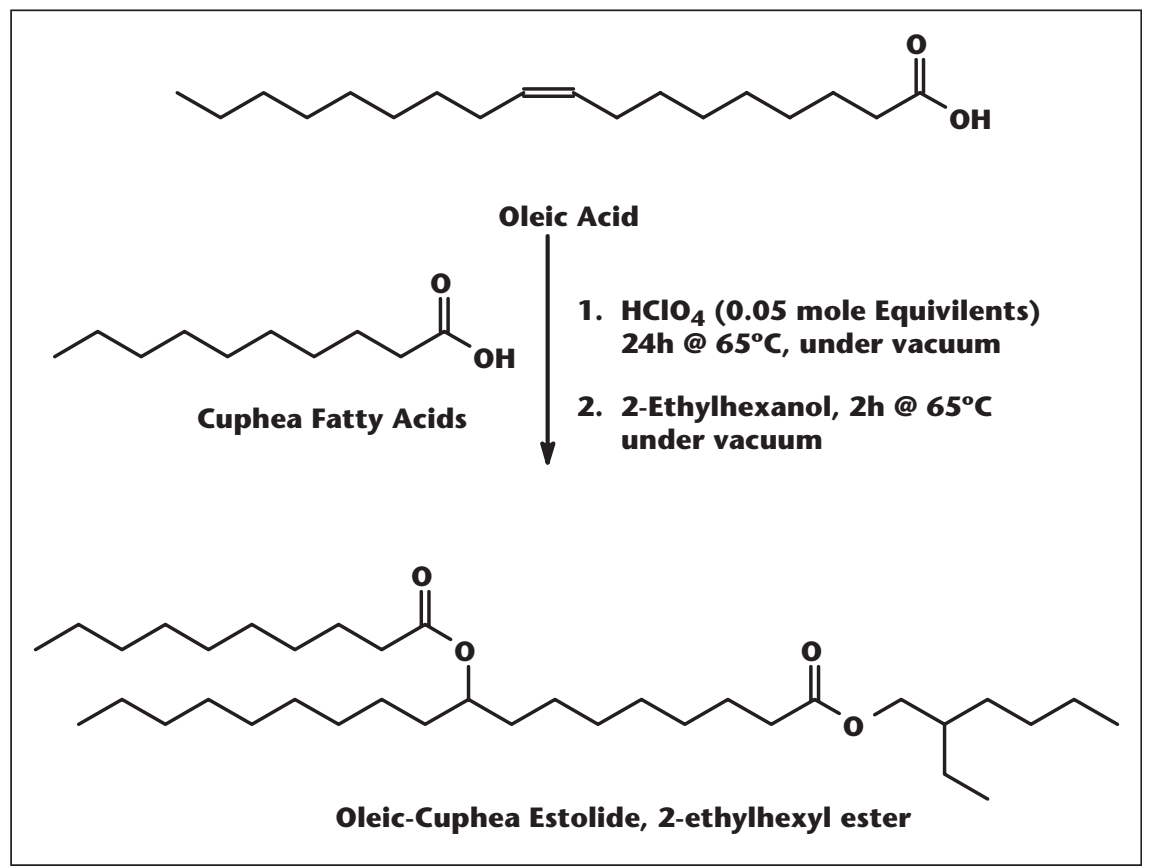

Figure 2. Synthesis of cuphea-oleic estolide.

Table 4. Comparison of cuphea-oleic estolide to commercially available oils.

\begin{tabular}{|llclc|}
\hline Lubricant & $\begin{array}{l}\text { Pour Point } \\
\left({ }^{\circ} \mathbf{C}\right)\end{array}$ & $\begin{array}{l}\text { Cloud Point } \\
\left({ }^{\circ} \mathbf{C}\right)\end{array}$ & $\begin{array}{l}\text { Viscosity } \\
\text { Index }\end{array}$ & $\begin{array}{l}\text { RBOT } \\
(\mathbf{m i n})\end{array}$ \\
\hline Commercial Soybean-based & -18 & 1 & 220 & 83 \\
Hydraulic oil & & & & \\
Commercial Synthetic Oil & -21 & -10 & 174 & 246 \\
Commercial Petroleum Oil & -27 & 2 & 152 & 223 \\
Oleic Estolide & -30 & -18 & 200 & 274 \\
Commercial Hydraulic Oil & -33 & 1 & 146 & 247 \\
Coconut-Oleic Estolide & -33 & -33 & 170 & 418 \\
Cuphea-Oleic Estolide & -42 & -41 & 170 & 420 \\
\hline
\end{tabular}

All the commercial oils in the table are fully formulated to enhance their physical properties the estolide samples only contain $1 \%$ of an antioxidant. rella are producing $2,016 \mathrm{~kg} / \mathrm{ha}$ of seed which contains $30 \%$ oil that is rich in lesquerolic acid (57\%) a hydroxy fatty acid homologue of ricinoleic acid found in castor oil. Table 5 compares the complete fatty acid profiles of both lesquerella and castor oils. Lesquerella contains approximately $60 \%$ hydroxy fatty acids compared to castor which has nearly $90 \%$ ricinoleic acid. Lesquerella has a substantial amount of linolenic acid at $12 \%$ where castor has none. This higher level of linolenic acid imparts reduced oxidative stability on many lesquerella derivatives and products but generally provides better cold temperature properties $[17,18]$. The increased chain length of lesquerella, 20 carbons versus 18 for castor tends to provide better lubricity for some lesquerella derivatives. Of particular note is the methyl ester derivative in lesquerella which has better performance in lubricating low sulfur diesel blends than the corresponding castor and soybean methyl ester blends [19]. Methyl lesquerolate at $0.2 \mathrm{wt} \%$ in ultra low sulfur diesel provided sufficient lubricity to pass the High Frequency Recipocating Rig (HFRR) test ISO limit of $0.45 \mathrm{~mm}$ wear scar where both soybean and castor methyl esters failed. Castor methyl ester blends passed at $0.5 \mathrm{wt} \%$ and soybean required $3 \%$ for the blend to meet the ISO specification.

Hydroxy fatty acids are used in a wide range of products; lithium greases, gelling agents, industrial lubricants, paints, coatings and polymers. Lesquerella oil can engage in a number of rich organic chemistry reactions (figure 3 ) do to its homologues relationship to ricinoleic acid. This chemistry can lead to production of detergents and monomers for the synthesis of long chain nylons. In addition, several esterification routes can lead to estolides (figure 4) which can provide molecules with good low temperature properties. Furthermore, some varieties of lesquerella (auriculata) contain large amounts of natural estolides (90\%) within their seed oil [20].

Table 5. Fatty acid composition of lesquerella and castor oils.

\begin{tabular}{|lcc|}
\hline Fatty Acid & Lesquerella & Castor \\
\hline $16: 0$ & 1.1 & 1.0 \\
$16: 1$ & 0.7 & \\
$18: 0$ & 1.8 & \\
$18: 1$ & 15.4 & 3.7 \\
$18: 2$ & 6.9 & 4.4 \\
$18: 3$ & 12.2 & \\
$20: 1$ & 1.0 & \\
$18: 1$ Hydroxy & 0.6 & 89.0 \\
20:1 Hydroxy & 55.4 & 1.1 \\
20:2 Hydroxy & 3.8 & \\
\hline
\end{tabular}




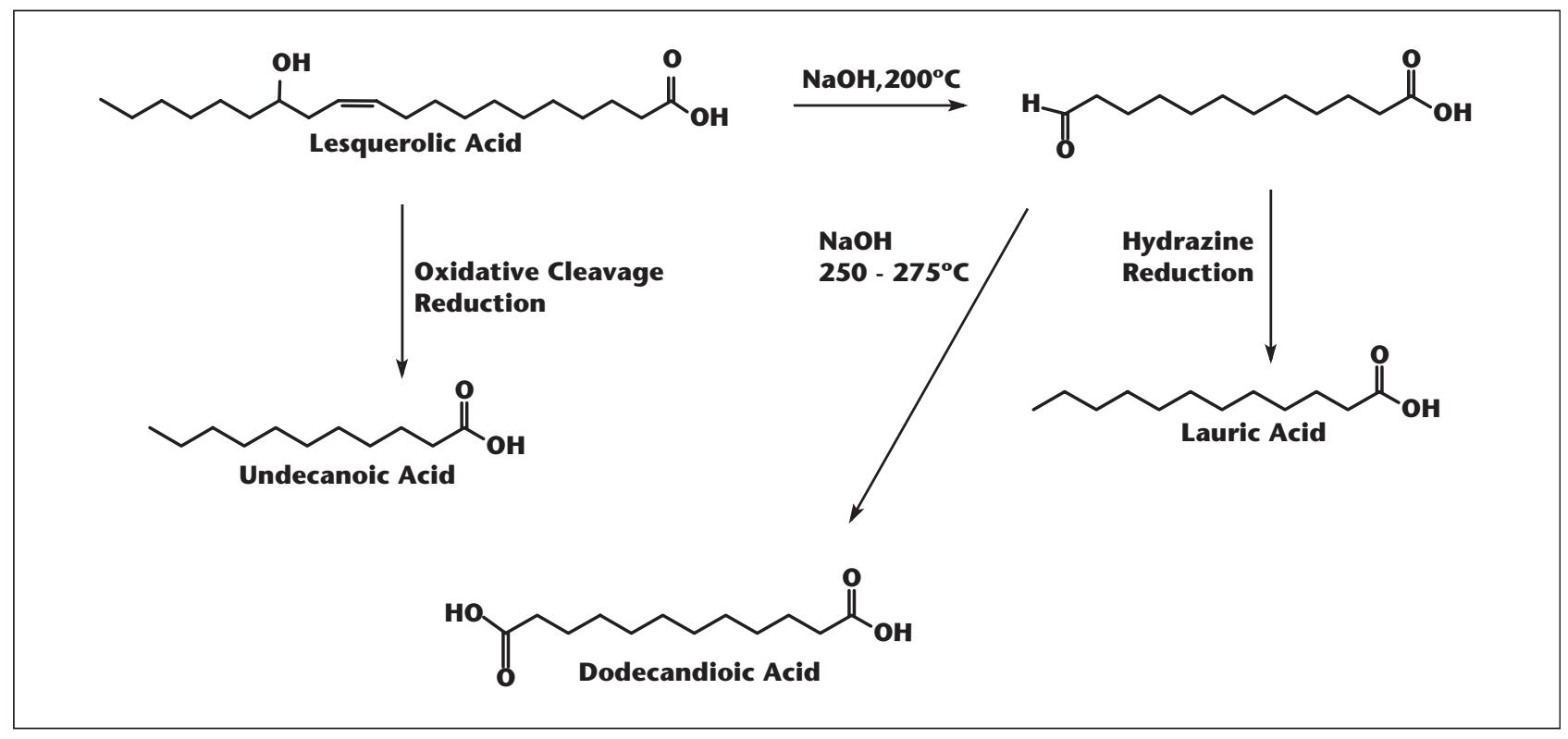

Figure 3. Historic alkaline cleavage of hydroxy fatty acids.

\section{Pennycress}

Pennycress (thlaspi arvense) is a mustard family member that grows as a winter annual across much of the Midwestern US and the world [21]. Pennycress is planted and emerges in the fall then over-winters as a small rosette. During the winter months small amounts of growth occur during the few widely scattered mild days within winter. In the spring the plant ramps into prolific growth and bolts in early April. After two/three weeks of flowering the seed has been fully set by early May and the crop desiccates over the remainder of the month with harvest of mature dry seed by the first week of June. The early harvest of pennycress allows growers to establish a full season soybean crop immediately following pennycress. Field harvest by combine is currently yielding 1,420 kg/ha seed. Hand harvest of $1 \mathrm{~m}^{2}$ block within these bulk fields indicated yield potential up to $1,534 \mathrm{~kg} / \mathrm{ha}$.

Currently there are 17 known accessions of thlaspi in the National Plant Germplasm system [22] and these accessions offer a diverse range of chemical and agronomic traits. Table 6 outlines the fatty acid profile of the Illinois pennycress currently under development. Erucic acid is the largest fatty acid observed at $36.9 \%$ with linoleic and linolenic acids as the other two major components of the oil. The high linolenic acid content reduces the oxidative stability of the oil (table 7). Fortunately, the low degree of saturates within the oil helps impart improved cold temperature properties making this oil superior to a number of other biodiesels derived from vegetable oils. Table 7 presents the initial physical properties of both pennycress oil and its methyl ester with respect to the ASTM requirement for a biodiesel. As a crude oil pennycress meets all of the ASTM requirements with the exception of acid value which may be addressed when fully cultivated seed is crushed and converted to methyl esters. Of particular note is the decent cold temperature performance represented by both cloud and pour points. As expected, the oxidative stability (OSI) just exceeds the requirement.

Pennycress seed and its defatted seed meal contain a glucosinolate, sinigrin, when released can serve as a volatile biofumigant [23]. Both, hexane extracted and expelled pennycress meals when placed in contact with water released allyisothiocyanate the aglycone of sinigrin found in pennycress seeds by action of the active myrosinase enzyme. Pennycress meal was shown to be effective at inhibiting the germination and growth of weed seeds in laboratory test experiments as well as test plots. Seedmeal when incorporated at $1.0 \mathrm{wt} \%$ into soil, particularly when the plots were covered to prevent volatiles from escaping, completely inhibited the appearance of weeds. This practice may be useful for organic growers who may be looking for green practices for weed control within field plots.

\section{Conclusion}

New Crops development effort in the US is focused on the advancement of crops that can be grown offseason or on underutilized land. This manuscript outlined four crops that address these concerns plus provide novel materials not currently available domestically. Cuphea still has many agronomic issues and will require the most technological breakthroughs before a sustainable crop can be grown. However, successful cuphea production would fill a much needed demand by the detergent industry. Coriander has already been grown commercially in other parts of the world for herb and condiment uses but production as an oilseed has not been commercially demonstrated. Successful production after winter wheat may make this crop economical for both detergents and monomers in nylon production. Lesquerella will provide a much needed crop to the desert regions of the US and fill a need for domestic production of hydroxy fatty acids. The agronomics of lesquerella look favorable and commercial production in the fall of 2009 is anticipated. The chemistry of lesquerella oil has been well demonstrated and will be able to readily supplement many applications currently using castor oil and provide a new raw material for additional applications. Pennycress has great promise as a winterspring production of fuel that will not displace a food crop, soybean, for its production. Many 


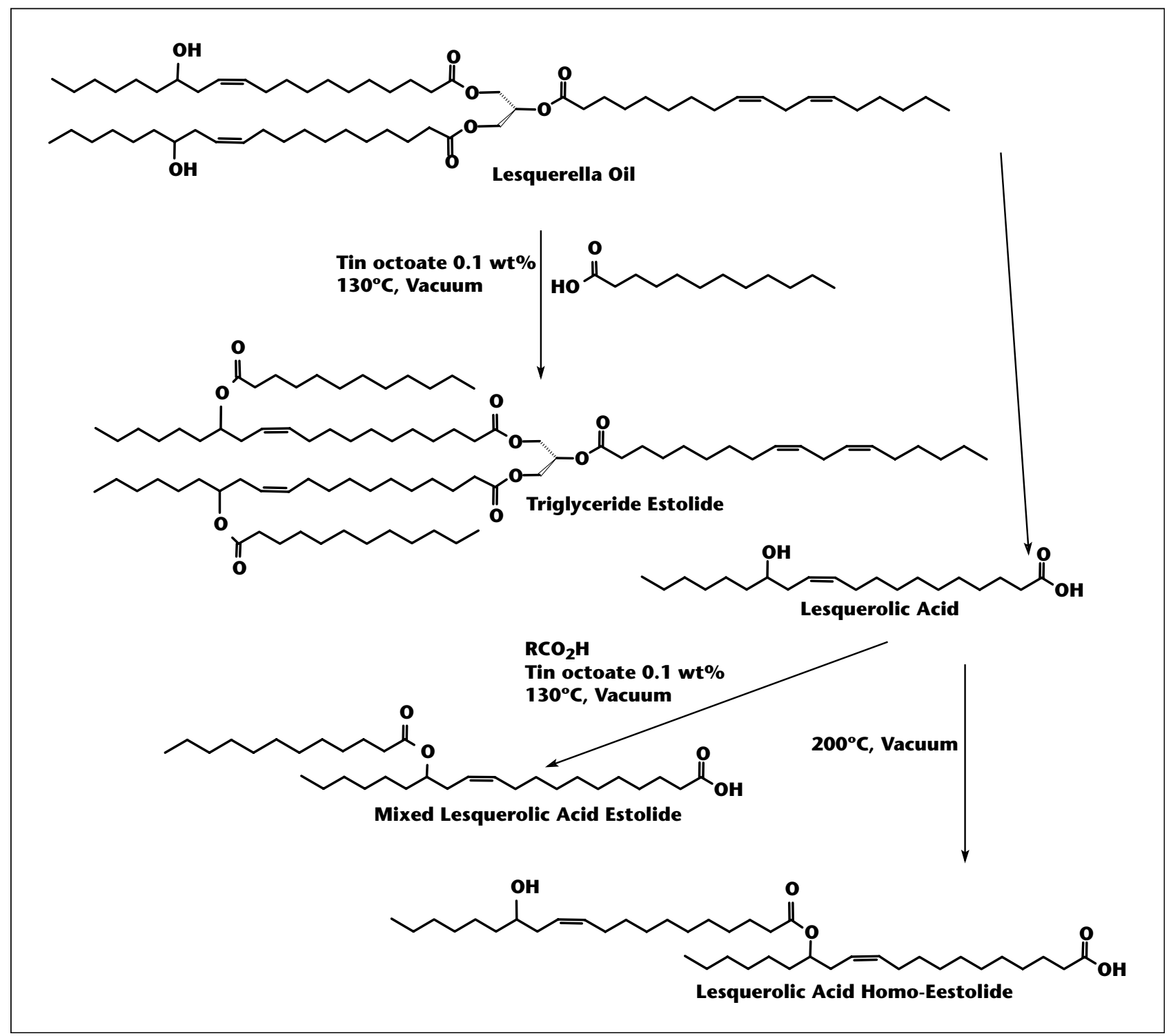

Figure 4. Synthesis of estolides from Lesquerella.

Table 6. Fatty acid composition of thlaspi (pennycress) collected from Illinois.

\begin{tabular}{|lc|}
\hline Fatty Acid & Percent \\
\hline $16: 0$ & 2.4 \\
$18: 1 \mathrm{D} 9$ & 9.7 \\
$18: 1 \mathrm{D} 11$ & 1.3 \\
$18: 2$ & 20.8 \\
$18: 3$ & 13.8 \\
$20: 1$ & 9.1 \\
$20: 2$ & 1.9 \\
$22: 1 \mathrm{D} 13$ & 36.9 \\
$22: 2$ & 0.8 \\
$24: 1$ & 3.2 \\
\hline
\end{tabular}

Table 7. Physical properties of pennycress oil and methyl esters.

\begin{tabular}{|llll|}
\hline & Oil & Methyl esters & ASTM requirements \\
\hline Viscosity Index & 222 & 277.0 & NA \\
$40{ }^{\circ} \mathrm{C}$ & 39.1 & 5.0 & $1.9-6.0$ \\
$100^{\circ} \mathrm{C}$ & 9 & 2.0 & $\mathrm{NA}$ \\
Pour Point $\left({ }^{\circ} \mathrm{C}\right)$ & -18 & -15.0 & $\mathrm{NA}$ \\
Cloud Point $\left({ }^{\circ} \mathrm{C}\right)$ & -10 & -10.0 & Report \\
Acid Value (mg KOH/g Oil) & 1.084 & 0.7 & $<0.5$ \\
Flash Point $\left({ }^{\circ} \mathrm{C}\right)$ & 234 & 136 & $>93$ \\
RBOT (avg min) & 17.5 & 12.5 & $\mathrm{NA}$ \\
RBOT w/antiox. (avg min) & 39 & 54.0 & $\mathrm{NA}$ \\
Copper Corrosion & $1 \mathrm{~B}$ at $51{ }^{\circ} \mathrm{C}$ & $1 \mathrm{a}$ & $<3$ \\
OSI (avg hours at $\left.110{ }^{\circ} \mathrm{C}\right)$ & 4.09 & 5.6 & $>3$ \\
\hline
\end{tabular}


agronomic parameters for pennycress still need to be addressed but limited commercial production is expected for the fall of 2009.

Acknowledgements. The author thanks scientists, technicians and students who have performed many parts of this research and have shared co-authorship on numerous peer reviewed manuscripts and abstracts. Those peers who have contributed most directly to this effort are: Dr. Steve Cermak, Dr. Robert Behle, Dr. Steve Vaughn, Dr. Roque Evangelista, Dr. Laura Marek, Dr. David Dierig, Dr. Candy Gardner, Dr. Russ Gesch, Dr. Winn Phippen, Dr. Stephanie Cape, Dr. Pedro Lopez, Dr. Mark Widrlechner, Ben Lowery, Amber John, Melissa Winchell, Linda Manthey, Molly Gass, Chelsey Rolando, Melissa Mund, Jeff Forrester and Billy Deadmond. Special thanks to the local farmers who allowed us access to their farms and expert advice on local farming practices: Donnie Meehan, Roger Beecher, Chip Unsicker, Fred Basehoar, George Geier and John Ackerman.

\section{REFERENCES}

1. National Agriculture Statistics Service. http:// www.nass.usda.gov/QuickStats/index2.jsp, 2009.

2. Arganosa GC, Sosulski FW, Slikard AE. Seed yields and essential oil of northern-grown coriander (Coriandrum sativum L.). J Herbs Spices Med Plants $1998 ; 6$ : 23-32.

3. Msaada K, Hosni K, Taarit MB, Hammami M. Marzouk. Effects of growing region and maturity stages on oil yield and fatty acid composition of coriander (Coriandrum sativum L.) fruit. Scientia Horticulturae 2009 ; 120 : 525-31.
4. Blade S. Coriander. http://www1.agric.gov.ab. ca/\$department/deptdocs.nsf/all/agdex121. 1998.

5. Lopez P, Widrlechner M, Simon P, et al. Assessing phenotypic, biochemical, and molecular diversity in coriander (Coriandrum sativum L.). Germplasm, 2007.

6. Murphy DJ. Designer oilseed crops: genetic engineering of new oilseed crops for edible and non-edible applications. Agro-Industry Hi-Tech $1991 ; 2: 5-9$

7. Goebel CG. Chemical intermediates and derivatives from unsaturated oils and acids. I Am Oil Chem Soc $1959 ; 36: 600-4$.

8. Isbell TA, Behle RW. Progress in the development of cuphea as a crop for Midwest growers. Inform 2003 ; $14:$ :513-5.

9. Forcella F, Gesch RW, Isbell TA. Seed yield, oil and fatty acids of cuphea in the northwestern corn belt. Crop Science $2005 ; 45:$ 2195-202.

10. Knapp SJ. Breakthroughs towards the domestication of p. 372-379. In: J. Janick J, Simon JE (eds), New Crops. John Wiley \& Sons, New York, 1993.

11. Knapp SJ, Crane JM. Registration of reduced shattering Cuphea germplasm PSR23. Crop Sci $2000 ; 40: 299-300$.

12. Knapp SJ, Crane JM. Registration of high oil Cuphea germplasm VL186. Crop Sci $2000 ; 40$ : 301.

13. Behle RW, Hibbard BE, Cermak SC, Isbell TA. Examining cuphea as a potential host for western corn rootworm (coleoptera: chrysomelidae): larval development. J Econom Entomol 2008 ; $101: 797-800$.

14. Behle RW, Isbell TA. Evaluation of cuphea as a rotation crop for control of western corn rootworm (coleoptera: chrysomelidae). J Economic Entomol 2005 ; 98 : 1984-91.
15. Cermak SC, Isbell TA. Synthesis and physical properties of cuphea-oleic estolides and esters. J Am Oil Chem Soc 2004 ; 81 : 297-303.

16. Cermak SC, Isbell TA. Estolides-the next biobased functional fluid. Inform $2004 ; 15$ : 515-7.

17. Isbell TA, Lowery BA, Dekeyser SS, Winchell ML, Cermak SC. Physical properties of triglyceride estolides from lesquerella and castor oils. Industrial Crops and Products $2006 ; 23$ : 256-63.

18. Moser BR, Cermak SC, Isbell TA. Evaluation of castor and lesquerella oil derivatives as additives in biodiesel and ultralow sulfur diesel fuels. Energy and Fuels $2008 ; 22$ : 1349-52.

19. Goodrum JW, Geller DP. Influence of fatty acid methyl esters from hydroxylated vegetable oils on diesel fuel lubricity. Bioresource Technology $2004 ; 96: 851-5$.

20. Kleiman R, Spencer GF, Earle FR, Nieschlang HJ. Tetra-acid triglycerides containing a new hydroxy eicosadienoyl moiety in lesquerella auriculata seed oil. Lipids $1972 ; 7$ : 660-5.

21. Carr P. Potential of fanweed and other weeds as novel industrial oilseed crops. In : Janick J, Simon J, eds. New Crops Exploration, Research and Commercialization. NY: John Wiley and Sons, Inc., 1991 : 384-8.

22. Marek LF, Bingaman B, Gardner CA, Isbell TA. Thlaspi arvense (2008). A potential biodiesel crop: preliminary evaluation of the USDA germplasm collection. Abstracts of the AAIC annual meeting. http://www.aaic.org/08progrm. htm\#POSTER_PRESENTATIONS_(Oilseeds)

23. Vaughn SF, Isbell TA, Weisleder D, Berhow MA. Biofumigant compounds released by field pennycress (thlaspi arvense) seedmeal. / Chemical Ecology $2005 ; 31$ : 167-77. 